Yuriy Turyanskyy. Ways of improving the analytical tools of the mechanism of tax regulation of Ukraine. Економічний дискурс. 2020. Випуск 3. С. 45-53.

DOI: https://doi.org/10.36742/2410-0919-2020-3-5

УДК 336.221.26(477)

JEL Classification E62, H21, H26

\author{
Yuriy Turyanskyy \\ Doctor of Economics, Associate Professor, Professor \\ Department of Economics \\ Lviv Regional Institute of Public Administration National Academy \\ for Public Administration under the President of Ukraine \\ Lviv, Ukraine \\ E-mail: yurtur@gmail.com \\ ORCID ID: 0000-0002-4892-0653
}

\title{
WAYS OF IMPROVING THE ANALYTICAL TOOLS OF THE MECHANISM OF TAX REGULATION OF UKRAINE
}

\footnotetext{
Abstract

Introduction. Deviations and imbalances that arise in the process of implementing the planned amounts of tax revenues require the implementation of a number of financial and economic measures through prompt intervention in the process of implementing the revenue side of the budget, ie tax regulation. Ensuring stabilization of the country's development is possible under the condition of reforming tax regulation, the priorities of which are de-shadowing of the economy, reducing the number of taxes and fees and creating incentives for small and medium business development, which actualizes the scientific search

Methods. Systemic, institutional methods (for the study of the tax system of Ukraine and mechanisms for regulating tax relations), the method of trend analysis (for the analysis of the dynamics of the tax burden on consumption, the analysis of tax coefficients of direct and indirect taxes) are used. Eurostat data on the main tax aggregates of national accounts of different countries, statistical and analytical information of the State Tax Service of Ukraine, the State Statistics Service of Ukraine, the Ministry of Finance of Ukraine were used as an information source.

Results. The task of tax regulation is to regulate supply and demand with the help of direct and indirect taxes, the formation of analytical tools for the mechanism of tax incentives for economic activity. Analytical tools of the tax regulation mechanism are proposed to be supplemented by monitoring the parameters of the tax burden in general and in terms of tax efficiency of direct and indirect taxes; econometric models for forecasting the level and impact of the tax burden on the macro parameters of economic stabilization. Their introduction will make it possible to more accurately identify areas for reforming the tax system to improve the efficiency of tax regulation.

Discussion. In further research, it is advisable to substantiate the priority areas of reforming the tax system of Ukraine to stabilize economic processes and develop practical recommendations for improving tax instruments.

Keywords: tax system, tax burden, directions of reform, shadow economy, monetary sphere.

\section{Introduction.}

In the process of fiscal and economic activities to implement the planned amounts of tax revenues there are certain deviations and imbalances, which requires a number of financial and economic measures through prompt intervention in the implementation of the revenue side of the budget, ie tax regulation. Despite the fact that Ukraine entered the economic crisis caused by the Covid-19 pandemic with a balanced macro-situation, the scale of the decline in economic activity due to quarantine restrictions
} 
indicates that the economic recovery process will be difficult.

Ensuring the stabilization of the country's development is possible provided that tax regulation is reformed, the priorities of which are de-shadowing of the economy, reduction of taxes and fees and creation of incentives for the development of small and medium-sized businesses. Thus, the scientific search for ways to increase the efficiency of the tax burden in Ukraine is relevant.

\section{Analysis of recent research and publications.}

Scientists and practitioners have made a significant contribution to the development of issues of improving the tax burden, in particular, on the methods of assessment, the impact on business activity, the implementation of tax obligations. O.M. Desyatnyuk and I.A Guzela [4] investigated the place of tax regulation in the implementation of effective tax transformations and identified problems in the context of imperfect regulatory framework of taxation, the complexity of the tax administration procedure, the spread of tax evasion. It should be noted that the researchers outlined the directions of modernization of tax regulation with a focus on the optimal combination of fiscal and regulatory functions of taxes to harmonize and harmonize the interests of taxpayers and the state.

V.Ye. Slyusarenko and K.O Philip [9] considered the impact of the level of taxation on such a characteristic as the shadowing of the economy and suggested appropriate ways to reform the tax system to overcome this threat.

V.V Koroviy highlighted the basic principles of tax policy, in particular the observance of the goals of fiscal sufficiency, economic efficiency, social justice, stability, adaptability and neutrality [6]. The author has developed a position to increase the effectiveness of the adaptively functional institutional architecture of tax regulation of socio-economic development of the country.

A group of scientists (Y.Turyansky, I. Svydruk, etc.) conducted a systematic study of the peculiarities of the current tax mechanism in Ukraine, which revealed the reasons for the increase in the tax burden and assess the impact of taxes on economic development, and justify proposals to revise tax rates, introduction of tools for macroeconomic risk management, customs post-audit [16].

Valuable information for further research is provided by foreign scholars, in particular D. Giovanni, F. Lamantia, M. Pezzino considered the problem of optimizing tax control aimed at maximizing the expected flow of tax revenues [15], and their results included conditions for approaching asymptotically stable domestic balance.

J. Cerdá, C. Montoliu, R.J. Colom proposed a model of global income distribution [13] that can be used to study tax regulation strategies. One of the most interesting features of the model is its complete discreteness, which allows its accurate implementation on any digital resource. Obtained by E.W. Bond and T.A. Gresik's findings suggest the importance of setting targets for tax transformations [12].

S. Auray, A. Eyquem, X. Ma highlighted the phenomenon of growing structural imbalances in tax systems [10], which allows us to assess the opportunities and threats for Ukraine in the field of competitive tax reform. The long-term consequences of tax reform are described by P. Benczúr, G. Kátay, Á. Kiss [11].

Thus, the analysis of scientific research provides a significant informative impetus to improve the domestic tax system. However, for the practical application of scientific developments it is necessary to: 1) apply a systematic approach to understanding the essence of the tax burden; 2) the choice of the structure of indicators for measuring the tax burden 3) justification of the criteria for the transformation of the tax burden. Paying tribute to the work of scientists in this field, it should be noted that in-depth research requires theoretical and methodological approaches to the study of the nature and tools of tax regulation.

\section{Purpose.}

The purpose of the article is to propose and substantiate the addition to the current analytical tools of the mechanism of tax regulation of Ukraine to increase the efficiency of the tax burden. 


\section{Research methodology.}

Systemic, institutional methods (for the study of the tax system of Ukraine and mechanisms for regulating tax relations), the method of trend analysis (for the analysis of the dynamics of the tax burden on consumption, the analysis of tax coefficients of direct and indirect taxes) are used. Eurostat data [14] on the main tax aggregates of national accounts of different countries, statistical and analytical information of the State Tax Service of Ukraine [2], the State Statistics Service of Ukraine [3], the Ministry of Finance of Ukraine [7] were used as an information source.

\section{Results.}

Tax policy, as part of the tools of national socio-economic development, provides management of the economic system by central government. According to the provisions of the Tax Code of Ukraine, tax policy is implemented through tax regulation mechanisms taking into account objective economic laws for balanced development of all industries and regions of the country, coordination of economic processes in accordance with the target direction of innovation development [1]. The effectiveness of the tax mechanism is determined primarily by the results of tax control, which is a form of control of taxes and is the final stage of planning and organizational tax work, and its direct purpose is a systematic activity aimed at approximating the actual implementation of tax revenues to the budget. indicators.

Analysis of the state and mechanisms of tax policy in the modern global economy is the basis for the separation of universal tax methods of crisis management. An important prerequisite for the optimization of tax regulation is the identification of system hypotheses for the calculation of the tax burden as elements of the transformation mechanism.

According to the theory of optimization of tax regulation of economic processes, all taxes generate certain deformations, ie the state with the help of certain taxes overcomes or reduces certain deformations. Based on this provision, to ensure the stabilization of the economy, it is necessary not just to reduce the level of taxes in GDP, to minimize the excess tax burden, to transform the size and types of tax revenues. The second hypothesis regarding the tax regulation of the economy is that the effectiveness of tax regulation is determined not so much by the direction of transformation as by the form and components, the impact of taxes on macroeconomic indicators is determined not by the tax burden but by individual elements of the tax system.

Tax regulation is a consequence of the regulatory function of taxes with its inherent contradictions, arising from the fiscal nature of the nationalization of part of the value of GDP. On the one hand, the task of tax regulation is to maximize the revenues of state and local budgets needed to finance the growing needs and functions of the national scale; on the other hand, tax levers and instruments are mechanisms for increasing financial capital and further growth of national wealth on this basis. Thus, the ultimate goal of tax regulation is to balance the interests of all subjects of taxation: the state in the face of authorized tax authorities, taxpayers - individuals and legal entities, households.

The specificity of modern conditions of tax regulation requires the introduction of a transformation mechanism (Fig. 1), which would combine tools aimed at macroeconomic stimulation of demand, supply and redistribution of income in the direction of ensuring equal taxation and reducing income differentiation. In such a mechanism, the regulatory efficiency of taxation must be combined with its fiscal sufficiency.

In Ukraine, national taxes are: corporate income tax, personal income tax, value added tax, excise tax, environmental tax, land tax (individuals), state duty and rent. In 2014-2019, the burden ratio for direct taxes, which include income tax, personal income tax, real estate tax, land tax, single, transport, environmental taxes, was in the range of 1.8-5.3\%. The burden ratio for indirect taxes, which include VAT, excise taxes, import and export duties was in the range of 10.8-14.2\%. Comparing the rates of certain types of taxes in Ukraine and the EU (Table 1), we conclude that tax rates are quite low, in particular, personal income tax rates. 


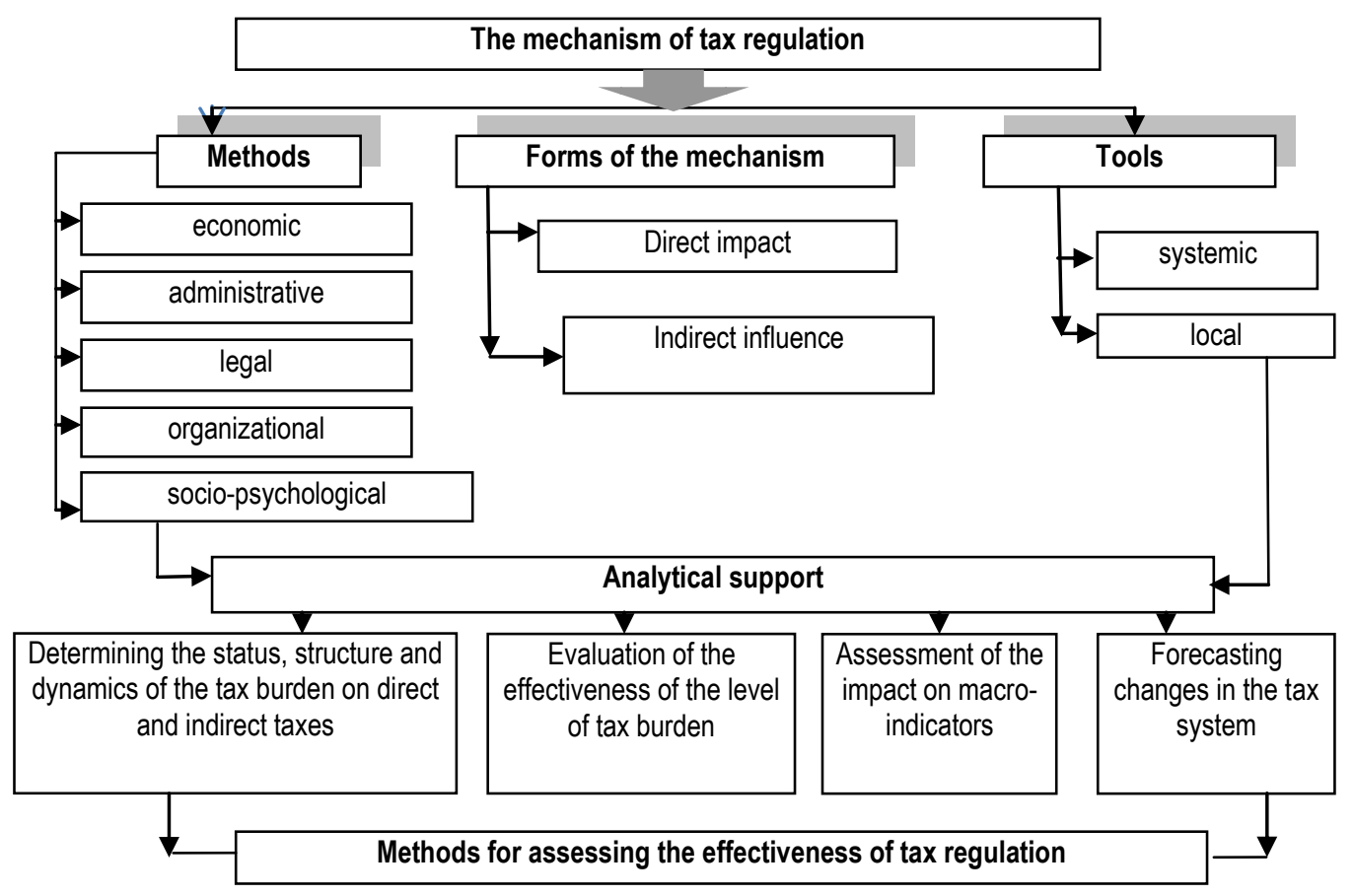

Fig. 1. The structure of the transformational mechanism of tax regulation * *Source: author development.

Table 1. Rates of individual taxes in Ukraine and some EU countries*

\begin{tabular}{|c|c|c|c|c|c|c|c|c|}
\hline Tax,\% & 竞 & 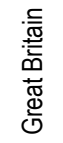 & 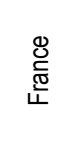 & $\frac{E}{\frac{E}{7}}$ & 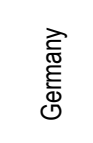 & 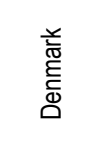 & 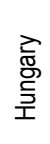 & 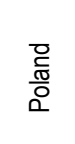 \\
\hline $\begin{array}{l}\text { Tax on } \\
\text { profit of enterprises }\end{array}$ & $\begin{array}{l}32012 \text { p. }-21 \\
32013 \text { p. }-19 \\
32014 \text { p. }-16 \\
\end{array}$ & 25 & 33,33 & $\begin{array}{l}24,9 \\
8,31 \\
34,5 \\
\end{array}$ & $30-33,3$ & 25 & 10 & 19 \\
\hline $\begin{array}{l}\text { Tax on } \\
\text { income of individuals }\end{array}$ & $\begin{array}{c}\text { Depending on the volume and } \\
\text { sources of income }-0,1,5 \text {, } \\
15,17,30\end{array}$ & $0-50$ & до 40 & $25-50$ & $15-45$ & $38-51,5$ & 16 & 18,32 \\
\hline $\begin{array}{l}\text { Tax on } \\
\text { added value }\end{array}$ & 20 & 17,5 & 19,6 & 21 & 19 & 25 & 25 & 22 \\
\hline
\end{tabular}

*Source: calculated from data [7; 14].

Indicators of the tax burden (Fig. 2) at the macro level reflect the effectiveness of tax policy, ie quantify the total impact of tax payments on the sources of their payment. At the same time, the general dynamics of macroeconomic processes in Ukraine indicates the need to intensify the redistributive function of taxes to limit the existing excessive income differentiation. 


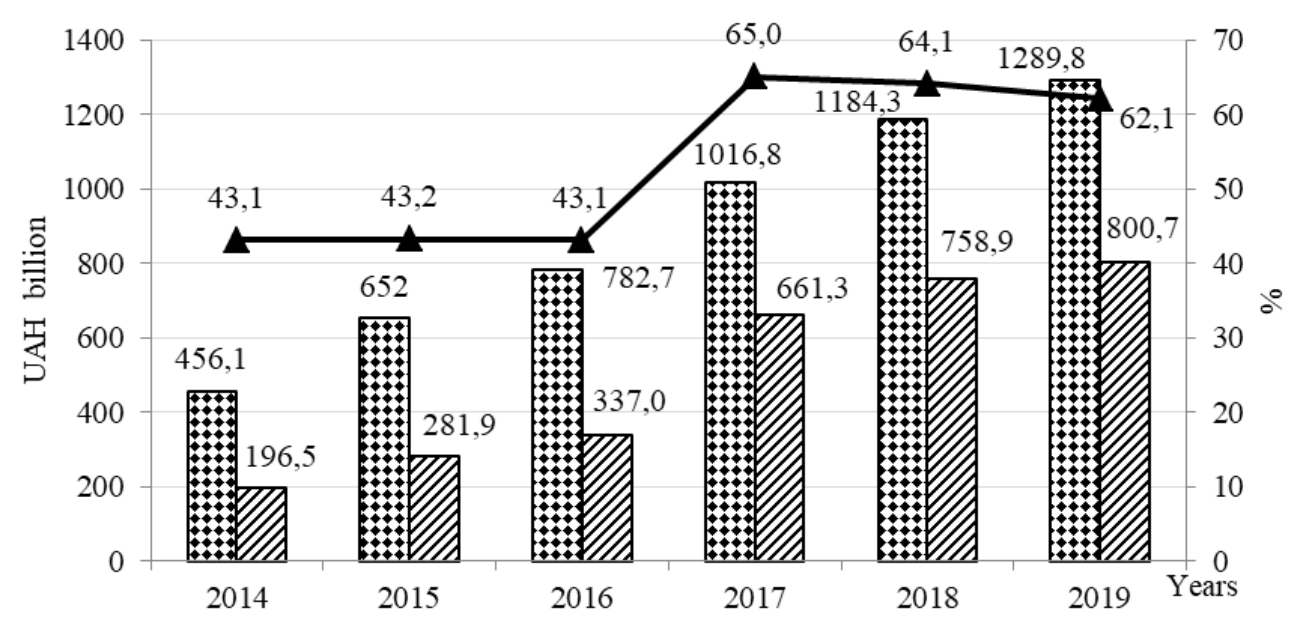

Fi: Consolidated budget revenues, UAH billion

men Consumption taxes, UAH billion

$\leftarrow$ Share of consumption taxes in budget revenues, $\%$

Fig. 2. Dynamics of the tax burden on consumption in Ukraine *

* Source: calculated from data [7].

Traditionally, to assess fiscal efficiency and determine the change in tax revenues depending on the change in GDP as the main indicator of economic growth use the indicator of tax elasticity [8]:

$$
R f e=\frac{\Delta T B / T B_{0}}{\Delta G D P / G D P_{0}},
$$

where $\triangle T B$ - increase in the tax burden of the study year; $T B_{0}$ - tax burden of the base year.

The coefficient of elasticity (direct and indirect) of taxes reflects changes in tax revenues when changing the relevant macroeconomic indicators or indicators of sustainable development, which are determined by the parameters of economic, environmental and social development. When Rfe $=1$ the share of tax revenues of the indicator is determined does not change. If $\mathrm{Rfe} \geq 1$, tax revenues grow faster than the growth of the macro indicator and the share of taxes in it also increases. If $\operatorname{Rfe}<1$, the share of tax revenues decreases.

Absolute and relative values of macro indicators can be used to calculate the coefficients of elasticity. The use of the tax burden indicator in the analysis of elasticity makes it possible to more accurately assess the priorities of tax policy, and the use of inverse indicators allows us to predict the level of macro indicators of sustainable economic development. The interests of economic entities coincide most fully with the value of the coefficient of elasticity equal to one. Other values violate the rights of the state or economic entities.

Positive for the economy can be considered long-term compliance with a low level of inelastic demand (increasing and tax revenues and the corresponding economic indicator, which is determined by the latter at a higher rate) or low elasticity of supply (increasing the share of taxes in the source of their payment does not prevent sufficient GDP growth). Conversely, it can be considered negative to maintain for a long time the value of the coefficients of elasticity of demand at the level of more than one, and the coefficients of elasticity of supply - much less than one. This indicates an unproductive increase in the tax burden, the inability of the current tax system to mobilize a sufficient amount of tax revenues to the budget, even with the growth of economic indicators due to the high level of tax burden and tax evasion. 
The natural reaction of the state to these negative trends in the economy should be to take appropriate measures to reduce the tax burden, improve the structure of the tax system, revise tax benefits, increase taxes and other ways to improve the efficiency of the current tax system. Thus, the described fiscal efficiency ratios must be taken into account when establishing the tax regime and the level of tax burden in the transformational mechanism of tax regulation.

For a comprehensive analysis of the fiscal efficiency of tax regulation, we propose to use a set of indicators and coefficients that characterize various aspects of economic relations arising from the functioning of taxes, namely: tax revenues and their share in revenues and tax revenues of the consolidated budget of Ukraine; the share of taxes in GDP and their fiscal efficiency in terms of GDP, models of the tax burden trend, models of the impact of the tax burden on macro indicators.

In Ukraine, the role of fiscal filling of the budget is performed with positive dynamics only by indirect taxes [5]. Trend models are used to predict the performance of the fiscal function of these taxes, and trend coefficients of tax coefficients are used to assess efficiency. To select the directions of change in the mechanism of tax regulation as an analytical tool, we use the model of the trend of tax coefficients to assess the dynamics of changes in the types of indirect taxation. According to the results of statistical evaluation of the obtained trend models of linear type (Table 2) based on the criteria of Student, Fisher and Darbin-Watson, we can say about the statistical probability of equations with probability $p=0,99$ (both in general and for individual parameters of the model) for such indicators of tax coefficients for indirect taxes such as taxes on consumption in general and excise duty.

Table 2. Equation of trends of tax coefficients for indirect taxes in Ukraine according to the data of 2014-2019*

\begin{tabular}{|c|c|c|c|c|}
\hline Показник & $\begin{array}{l}\text { Trend equation } \\
\text { and value } \\
t \text {-criterion Student }\end{array}$ & $\begin{array}{c}\text { Coefficient } \\
\text { determination } R^{2}\end{array}$ & $\begin{array}{l}\text { F-criterion } \\
\text { Fisher }\end{array}$ & $\begin{array}{c}D W \text { - criterion } \\
\text { Darbina- } \\
\text { Watson } \\
\end{array}$ \\
\hline Consumption taxes / GDP, $\%$ & $\begin{array}{c}\tilde{y}=11,39+0,22 t \\
24,58 \& 3,18^{\& \&}\end{array}$ & 0,529 & $10,12 \&$ & $2,12^{2 \&}$ \\
\hline VAT / GDP, $\%$ & $\begin{array}{c}\tilde{y}=9,13+0,01 t \\
24,93^{\&} 0,23\end{array}$ & 0,006 & 0,1 & $2,208 \&$ \\
\hline $\begin{array}{l}\text { Taxes on international trade and foreign } \\
\text { transactions / GDP, } \%\end{array}$ & $\begin{array}{c}\tilde{y}=1,10+-0,003 t \\
4,29 \&-0,07\end{array}$ & 0,001 & 0,00 & $2,27^{2 \&}$ \\
\hline Excise duty / GDP, $\%$ & $\begin{array}{c}\tilde{y}=1,16+0,21 t \\
6,27 \& 7,57 \&\end{array}$ & 0,864 & $57,4^{8}$ & $1,71^{2 \&}$ \\
\hline Excise duty on domestic goods / GDP,\% & $\begin{array}{c}\tilde{y}=1,25+0,08 t \\
7,67 \& 3,53 \&\end{array}$ & 0,581 & $12,5^{\&}$ & $1,50^{2 \&}$ \\
\hline Excise duty on imported goods / GDP, $\%$ & $\begin{array}{c}\tilde{y}=-0,08+0,12 t \\
-0,888,86^{\&}\end{array}$ & 0,897 & $78,4^{\&}$ & $1,13^{3 \&}$ \\
\hline
\end{tabular}

Note: ${ }^{\&}$ - statistical probability with probability $p=0,99$ (level of significance $\alpha=0,01$ ); \& - statistical probability with probability $p=0,95$ (level of significance $\alpha=0,05$ )

*Source: calculated from data [2; 3].

The coefficient of the linear equation of the trend $\tilde{y}=11,05+0,22 t$ shows that for the period from 2014 to 2019 the tax coefficient for indirect taxes increased annually by an average of $0,22 \%$. If this trend continues in the coming years, this tax rate will continue to grow. Excise duty for the study period increased annually by $0,16 \%$, as indicated by the coefficient of the linear model of the main development trend for this indicator $(\tilde{y}=1.26+0.16 t)$. The value of the trend equation coefficient $\tilde{y}=-0,08+0,12 t$ 
shows that the tax coefficient on excise duty on imported goods for $2014-2019$ increased by $0,12 \%$.

The absence of the main development trend for tax coefficients for such components of indirect taxes as value added tax and taxes on international trade and foreign transactions allows us to conclude that the state fiscal policy is unregulated on these indicators. Particular attention should be paid to the high statistical probability of the trend model of the tax rate on excise duty on imported goods. This reflects the state's hopes for a steady increase in tax revenues from excise duties on imported goods, not domestic ones.

To determine the directions of tax regulation, we propose to use the analytical tools of the trend models of tax coefficients for direct taxes, which determine the dynamics of supply. Analysis of the trend of relative indicators calculated by the value of direct taxes, gross domestic product and revenues to the consolidated budget showed that mostly all indicators of tax rates and tax burden indicate a downward trend (Table 3).

Table 3. Equation of trends in tax rates of direct taxes in Ukraine according to 2014-2019*

\begin{tabular}{|c|c|c|c|c|}
\hline Показник & $\begin{array}{l}\text { Trend equation } \\
\text { and value } \\
\text { t-criterion Student }\end{array}$ & $\begin{array}{c}\text { Coefficient } \\
\text { determination } \\
R^{2} \\
\end{array}$ & $\begin{array}{c}\text { F-criterion } \\
\text { Fisher }\end{array}$ & $\begin{array}{c}\text { DW- criterion } \\
\text { Darbina- } \\
\text { Watson }\end{array}$ \\
\hline Direct taxes / GDP,\% & $\begin{array}{c}\tilde{y}=10,65-0,41 t \\
20,08^{\&}-5,29^{\&}\end{array}$ & 0,757 & $28,0 \&$ & $1,09 \& \&$ \\
\hline Corporate income tax / GDP, $\%$ & $\begin{array}{c}\tilde{y}=5,32-0,27 t \\
16,13^{\&}-5,62^{\&}\end{array}$ & 0,778 & $31,6^{\&}$ & $1,65^{\&}$ \\
\hline Personal income tax / GDP, $\%$ & $\begin{array}{c}\tilde{y}=5,27-0,19 t \\
14,97 \&-3,61^{\&}\end{array}$ & 0,592 & $13,0^{\&}$ & 0,81 \\
\hline Single tax for small businesses / GDP, $\%$ & $\begin{array}{c}\tilde{y}=0,06+0,05 t \\
0,814,68 \&\end{array}$ & 0,709 & $21,9^{\&}$ & 0,63 \\
\hline Single tax on legal entities / GDP, $\%$ & $\begin{array}{c}\tilde{y}=0,08+0,003 t \\
5,051,41\end{array}$ & 0,180 & 2,0 & 0,64 \\
\hline Single tax on individuals / GDP, $\%$ & $\begin{array}{c}\tilde{y}=0,02+0,03 t \\
0,375,52^{\&}\end{array}$ & 0,772 & $30,5^{\&}$ & 0,97 \\
\hline
\end{tabular}

Note: \& - statistical probability with probability $p=0,99$ (level of significance $\alpha=0,01$ );

$\& \&$ statistical probability with probability $p=0,95$ (level of significance $\alpha=0,05$ )

* Source: calculated from data [2; 3]

The problem of determining the tax burden is exacerbated by the fact that about half of economically active businesses are in the shadows and at least half of taxpayers hide their tax revenues. The full tax burden is borne by only a small proportion of the economically active population of the state. This problem is one of the priorities in determining the tax burden, as the distortion of official data makes it impossible to correctly determine the tax pressure and make regulatory decisions.

The transformation of the tax burden for taxpayers in Ukraine concerns the redistribution of the tax burden between bona fide and shadow taxpayers and requires an improvement in the system of tax benefits. That is, the de-shadowing of the economy is one of the most important prerequisites for the ability to correctly determine and distribute the tax burden on businesses.

Thus, the real tax burden in Ukraine borne by law-abiding taxpayers is much higher than officially determined. The main reasons for this discrepancy are: the lack of a stable and long-term tax policy, scientifically sound priorities for its implementation; constant changes in tax legislation, which are practically difficult to track and implement; availability of a significant number of tax benefits and 
preferences provided to different categories of taxpayers; the existence of a mechanism of illegal shadow tax pressure; the presence of bribery and corruption, which makes it possible to avoid paying taxes and increases the tax debt.

These and other reasons are the basis for determining the methods and tools of the mechanism of transformation of tax burden regulation. To increase the efficiency of tax regulation, it is necessary to solve a number of problems, among which it is important to de-shadow the economy and create appropriate macroeconomic conditions to stimulate aggregate demand as a decisive factor in economic recovery, increasing production and thus expanding the tax base.

The priorities of de-shadowing of the economy in the context of tax regulation are the implementation of the following priorities: 1) ensuring equal conditions of taxation for all business entities; 2) reduction of the tax burden; 3 ) ensuring effective tax administration and stability of fiscal regulation. To implement these priorities, it is necessary to use the appropriate tools of the transformational mechanism of tax regulation. These include the following:

- conducting a tax amnesty on the basis of a transparent and clear procedure, which will increase business confidence in the state and the state in business and increase revenues to the state budget;

- increasing the role of electronic systems in tax administration, which will reduce the physical contact of taxpayers with taxpayers and improve the transparency of tax control;

- reduction of the tax burden and reduction of the number of mandatory payments and tax benefits, which will provide equal conditions for all taxpayers and reduce incentives to reduce the cases of minimization of tax liabilities;

- reforming the simplified system so that it includes only really small enterprises and not as a tool for shadowing financial flows;

- solving the problem of arrears of VAT refunds to support exports and increase business confidence in the state;

- strengthening the responsibility for the use of shadow tax schemes in doing business and intentional minimization of tax liabilities.

To stimulate the aggregate supply, the following preconditions are needed at the time of the introduction of the transformation mechanism: the predominance of individual incomes in the structure of GDP and their insignificant or acceptable stratification; sufficient level of development of the monetary sphere; insignificant or acceptable level of the shadow sphere; high tax culture of taxpayers and established tax traditions.

The analysis of the existing preconditions for the expansion of aggregate demand based on the analysis of indirect taxation through tax incentives indicates the need to develop structural and redistributive processes that affect the tax base, namely: streamlining subsidiary and preferential policies; revision of the structure of the tax burden, its sectoral distribution, tax base, application of incentive elements, in particular reduction of rates while maintaining their progression, provision of incentive investment and innovation benefits.

\section{Discussions.}

Income taxes act on the market as macroeconomic regulators, acting as financial levers that affect the efficiency of the national economy. The task of tax regulation is to regulate supply and demand with the help of direct and indirect taxes, the formation of analytical tools for the mechanism of tax incentives for economic activity.

Analytical tools of the tax regulation mechanism are proposed to be supplemented by monitoring the parameters of the tax burden in general and in terms of tax efficiency of direct and indirect taxes; econometric models for forecasting the level and impact of the tax burden on the macro parameters of economic stabilization. Their introduction will make it possible to more accurately identify areas for reforming the tax system to improve the efficiency of tax regulation.

In further research, it is advisable to substantiate the priority areas of reforming the tax system of 
Ukraine to stabilize economic processes and develop practical recommendations for improving tax instruments.

\section{References}

1. Verkhovna Rada Ukrainy. (2010). Podatkovyi kodeks Ukrainy. Retrieved from http://zakon1.rada.gov.ua/cgi-bin/laws/main.cgi?Nreg = 2755-17.

2. Derzhavna podatkova sluzhba Ukrainy. (2020). Zahalnoderzhavni podatky. Retrieved from https://www.tax.gov.ua/podatki-ta-zbori/zagalnoderjavni-podatki/

3. Derzhavna sluzhba statystyky Ukrainy. (2020) Makroekonomichni pokaznyky. Retrieved from http://www.ukrstat.gov.ual (accessed 20.07.2020).

4. Desiatniuk, O. M., \& Huzela, I. A. (2019). Problemy i napriamky modernizatsii podatkovoho rehuliuvannia $v$ Ukraini [Problems and directions of modernization of tax regulation in Ukraine]. Svit finansiv [World of Finance], 3 (56), 58-68. [in Ukr.].

5. Drozdovska, O. S., \& Ozerchuk, O. V. (2017). Spivvidnoshennia priamykh ta nepriamykh podatkiv u podatkovii systemi Ukrainy [The ratio of direct and indirect taxes in the tax system of Ukraine]. Investytsii: praktyka ta dosvid [Investment: practice and experience], 10, 44-50. [in Ukr.].

6. Korovii, V. V. (2019). Podatkova polityka u systemi ekonomichnoho rehuliuvannia [Tax policy in the system of economic regulation]. Investytsii: praktyka ta dosvid [Investments: practice and experience], 15, 20-26. [in Ukr.].

7. Ministerstvo finansiv Ukrainy. (2020) Makrofinansovi pokaznyky. Retrieved from https://minfin.com.ua/ua.

8. Savchenko, A. M., \& Blyshchyk, L. V. (2018). Analiz rivnia podatkovoho navantazhennia v konteksti implementatsii yevropeiskykh standartiv u natsionalnu ekonomiku Ukrainy [Analysis of the level of tax burden in the context of the implementation of European standards in the national economy of Ukraine]. Ekonomika ta derzhava [Economic Science], 5, 93-96. [in Ukr.].

9. Sliusarenko V. Ye., \& Filip, K. O. (2014) Vplyv rivnia opodatkuvannia na rozvytok ekonomiky abo yii tinizatsiiu [Impact of taxation on economic development or its shadowing]. Visnyk ZhDTU [The Journal of Zhytomyr State Technological University], 3 (9), 92-100. [in Ukr.].

10. Auray, S., Eyquem, A., \& Ma, X. (2017). Competitive tax reforms in a monetary union with endogenous entry and tradability. European Economic Review, 98, 126-143. doi:10.1016/j.euroecorev.2017.06.002.

11. Benczúr, P., Kátay, G., \& Kiss, Á. (2018). Assessing the economic and social impact of tax and benefit reforms: A general-equilibrium microsimulation approach applied to Hungary. Economic Modelling, 75, 441-457. doi:10.1016/j.econmod.2018.06.016.

12. Bond, E. W., \& Gresik, T. A. (2020). Unilateral tax reform: Border adjusted taxes, cash flow taxes, and transfer pricing. Journal of Public Economics, 184, 104-160. doi:10.1016/j.jpubeco.2020.104160.

13. Cerdá, J., Montoliu, C., \& Colom R. J. (2013). LGEM: A lattice Boltzmann economic model for income distribution and tax regulation. Mathematical and Computer Modelling, 57 (7), 1648-1655. Retrieved from https://doi.org/10.1016/j.mcm.2011.10.051.

14. Eurostat. (2020). Main national accounts tax aggregates. Retrieved from http:/l appsso.eurostat.ec.europa.eu/nui/show.do?dataset=gov_10a_taxag\&lang=en.

15. Giovanni, D., Lamantia, F., \& Pezzino M. (2019). A behavioral model of evolutionary dynamics and optimal regulation of tax evasion. Structural Change and Economic Dynamics, 50, 79-89. Retrieved from https://doi.org/10.1016/j.strueco.2019.05.004.

16. Turyanskyy, Y., Svydruk, I., Sydorchuk, O., Mitsenko, N., \& Klepanchuk, O. (2020). Management priorities of tax reform in Ukraine: implementation of international experience. Investment Management and Financial Innovations. 17, Is. 2. P. 320-333. Retrieved from http://dx.doi.org/10.21511/imfi.17(2).2020.25.

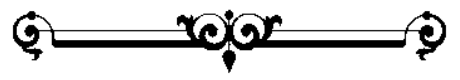

